\title{
An Exploratory Quantitative Study into the Relationship between Catholic Affiliation and the Development of Social Entrepreneurship and Non-profit Management Courses in the USA
}

\author{
Cherry Wun Mei Cheung* (London South Bank University, Business School), Sujun \\ Fieldhouse (Southend Borough Council) and Caleb Kwong (University of Essex, Business \\ School) UK
}

\begin{abstract}
Catholic educationalists have long stressed the role of Catholic universities in advancing the cause of social justice to counter the increasing commodification of business relationships and the lack of social responsibilities of the business world. Is this rhetoric or reality? In this empirical paper involving 501 USA universities that have an Association to Advance Collegiate Schools of Business (AACSB) accredited business school, we examine the relationship between Catholic affiliation and the universities' decisions to offer social entrepreneurship and non-profit management courses to business students. Our study found that universities with Catholic affiliation are significantly more likely to offer both non-profit management and social entrepreneurship courses to business students. Our results offer evidences that Catholic universities are indeed working towards making a difference, with the vision and flexibility to do so.
\end{abstract}

Keywords: Catholic universities, social entrepreneurship education, non-profit management courses, USA.

\section{Introduction}

In a world dominated by the backlash of capitalism and globalisation, business students are increasingly being scrutinized for their degree of social and moral responsibility. The wave of corporate scandal that emerged in recent years has led to fingers being pointed squarely at universities and business schools as responsible for producing self-serving executives and managers whose unethical and fraudulent behaviours contributed to the downfall of many once great organizations (Ghoshal, 2005; Rasche et al., 2013). Social entrepreneurship and nonprofit management educational initiatives are seen as an effective way to bridge the gap between the free market orientation of their curriculum and the negativities of the resulting individualistic, profit prioritizing mentality associated with the operation of free markets. Their implementation would enable universities to restore some of their creditability, as well as halting the erosion of public trust in their graduates. Unsurprisingly, these courses are increasingly being offered to business students. With their specialisms in management as well as entrepreneurship, business schools and colleges often take a lead in the designing and running of such courses, although it is important to note that the delivery of these courses can be part of a university-wide initiative and hence a collaborative effort between the business schools as well as other departments, most notably social work, government and engineering.

Whilst non-profit management courses have been around in universities for over a century, social entrepreneurship courses have only become popular in the past decade or so (Young, 1999; Austin et al., 2006). Although these two types of courses share notable similarities in terms of their fundamental values, there are substantial differences in terms of their pedagogical emphasis as well as their target audiences. Both these courses emphasise heavily the delivering of social justice through the enrichment of the understanding of the nature of social problems 
as well as encouraging appropriate actions to tackle them. However, whilst non-profit management courses focus on enriching the knowledge of the learners through the delivery of conventional management subjects including strategy, marketing, finance and human resources, a key feature of social entrepreneurship courses is the embeddedness of entrepreneurship theories and practices into their teachings, including emphasis on opportunity recognition in identifying social needs, drawing from the latest innovations across multiple business and managerial aspects of learning, and inspiring students to apply entrepreneurial practices, such as bricolage, or the use of resources at-hand for augmented purpose in a resource constrained environment ${ }^{1}$, in the implementation of social actions (Howorth, Smith and Parkinson, 2012). In terms of target audience, whilst non-profit management courses have a strong emphasis on preparing learners for a career in non-profit organisations, the catchment of social entrepreneurship courses is considerably more inclusive, encompassing learners from all walks of life, regardless of sector of involvement (Kwong, Thompson and Cheung, 2012). These courses are concerned with supporting not only non-profit leaders and managers to become more entrepreneurial, but also to support those who intend to start their own business ventures, as well as supporting those who are entering for-profit organisations to become more 'intrapreneurial', by actively thinking of innovative ways to address social challenges in their own profession ${ }^{2}$. The entrepreneurship emphasis, coupled with the inclusivity of target catchment, make social entrepreneurship courses highly popular amongst educational establishments and students. As a result, the number of social entrepreneurship courses at universities has increased considerably over the past decade (Lawrence, Philips and Tracey, 2012) $)^{3}$.

It is unquestionable that both of these courses sit well with the values and ethos of Catholicism. From the earliest Christian communities struggling to be compassionate and kind to the poor and needy in action (e.g. Matthew 25: 41-46, James 2: 14-17, 26), to the landmark encyclical Rerum Navarum (1891) by Pope Leo XIII addressing the social problems in post-industrial revolution societies, through to its modern contemporary, Pope Benedict XVI's Caritas in Veritate (2009), the emphasis on social justice has permeated Catholic social teaching. In Caritas in Veritate, Pope Benedict stressed that Catholic social teaching should derive from the life and teachings of Jesus as 'handed on by the Apostles to the Fathers of the Church' (para. 12). According to Grace (2013), Pope Benedict's encyclical Caritas in Veritate can be discerned as three major pillars: i) religious, moral and cultural issues; ii) economic, business and enterprise issues; and iii) social, environmental and political issues. Social entrepreneurship and non-profit management education cut across these themes. They intend to address societal and environmental problems through encouraging learners to behave morally and ethically, while at the same time adopting business and entrepreneurial approaches while doing so.

In fact, Catholic universities have been the pioneers in running non-profit management courses (O'Neil, 2005) and many of these are highly regarded (see USA News, 2016, Top Management Degrees, 2016). However, we know very little of the implementation of social entrepreneurship courses in Catholic universities. Nevertheless, the question of whether social entrepreneurship courses can become as popular as non-profit management courses is a crucial one, as their implementation reflects the flexibility of Catholic universities and their staff in adapting to changes in the external context, and responding to them accordingly with innovative, yet arguably less proven, methods and approaches. Whilst the pedagogical aspect of both of these 
courses is being increasingly understood (Lawrence, Phillips and Tracey, 2012), the reasons behind institutions' decisions to supply these courses, particularly for social entrepreneurship courses, remain largely unexplored. This, we believe, is an important research gap within the literature that we intend to address. Our research concerns the question of how these courses are being embraced by Catholic universities in the USA. Utilising a quantitative approach, we examine separately the relations between Catholic affiliation and the take-up of each of these courses, after controlling for a number of structural and strategic influences, such as the size of the cohort, endowment, the reputation of the university, and their social as well as entrepreneurial orientation in terms of their engagements in these areas.

In the following section, we provide an overview of the theoretical foundation of Catholic social teaching, after which we examine the historical receptiveness of Catholic educational establishments to the implementation of novel actions and initiatives towards the attainment of social justice. Sample, measures, as well as our approach to data analysis are discussed in the methodology section. Results from the data analysis are presented in the results section, followed by discussion and conclusion.

\section{The nature of Catholic Social Teaching (CST) and its impact on the curriculum development of Catholic universities}

The recent financial crisis provides strong evidence of the inherited weaknesses of neoliberalism, where short-term profit maximisation is seen as the be-all-and-end-all goal of businesses, and where endemic self-serving and irresponsible behaviours amongst leaders and employees of businesses created enormous destruction to the systems and the people within them (Hadas, 2009). Traditionally, business disciplines are where the students' expectations gear further towards the culture of neo-liberalism. For instance, McCabe and Trevino (1995) found that business school students placed least importance on equality and justice, and on developing a philosophy of life. Such culture may also be implanted within the design of many of these programmes, consequently further reinforcing such expectation. A study by the Aspen Institute (2001) found that, during the two years of an MBA programme, students placed an increasing importance on enhancing shareholders' benefits whilst at the same time became less interested in other people, including employees and even consumers. With the increasing popularity of business subjects and the growth of business schools being a growing feature of Catholic educational establishments across the world (Grace, 2013), such a self-centred worldview amongst business students and graduates presents an enormous challenge for Catholic universities to overcome. In Caritas in Veritate, Pope Benedict has outlined the danger of allowing a free-market ideology that is amoral to remain autonomous (para 34-39), and called on the leaders and managers of businesses to seriously consider the ethical foundation of their activities (para 65-77).

Echoing the call within the ethical and corporate social responsibility literature for a shift towards a holistic conception of business enterprise where business leaders and managers work towards a multi-stakeholder perspective (Spitzeck and Hansen, 2010; Brammer et al., 2012), Catholic social teaching scholars are increasingly emphasising ways in which common over private good can be prioritised and in doing so, encouraging businesses to work together for a cultural transformation, overhauling the existing business trends (Longley, 2014). Catholic social teaching can play a role in defining what can be considered the common good in a pluralistic world (Longley, 2014). In Catholicism, the 'golden rule', 'do unto others as you 
would have others do unto you', in addition to what Catholics consider the 'greatest commandment', 'Thou shalt love thy neighbour as thyself', form the foundation of the morality and humanity of their followers. In Gaudium et Spes (2016), common good is further defined as 'the sum total of social conditions which allow people, either as groups or as individuals, to reach their fulfilment more fully and more easily' (para 26), and, as an integral part of 'human development' (para 30). In turn, common good is underpinned by two concepts: 'solidarity' and 'subsidiarity' (Quadragesimo anno, 1931). 'Solidarity' emphasises that humans are social beings and are highly dependent on one another within society. They therefore have an obligation to support one another. However, solidarity should not only be shared with those nearest to us, but should be considered a universal principle that fosters the unity of the whole human family (Catechism of the Catholic Church, para 1911). The Catholic church has taken a broad definition of 'neighbour', taking into account the diverse needs of people, both believers and non-believers, across the world (Populorum Progressio, 1967, para 53), including but not limited to the poor (Populorum Progressio, 1967, para 23; Rerum Novarum, 1981, para 23), the helpless (Rerum Novarum, 1981, para 29), the marginalised (Pope John Paul II, Lenten message, 1998), and the powerless, voiceless and defenceless (Economic Justice for All, 1986, para 16 and 87). 'Subsidiarity' refers to a 'bottom-up' implementation process where each member of the Catholic church is individually responsible for delivering common good at the local level, as those who are close to the problems and issues are most acute to challenges and possible solutions. In combination, the Catholic church considers that 'solidarity' and 'subsidiarity' offer grounds for social action on an individual level, where every member of the Catholic Church has the right to enjoy the benefits brought about by the common good, but, at the same time, has a duty to develop and uphold it (Compendium, para 167).

Catholic universities play a crucial role in the permeation of these important Christian social values, and in particular, in empowering their students with better understanding of the need for solidarity and subsidiarity in pursuing common good for mankind. In order to do so, much of the emphasis is on the development of a curriculum that reflects the dual emphasis of academic excellence as well as the moral development of those who are going through their ranks. The writings of St. Thomas Aquinas, for instance, present a clear case of the necessity to develop a realisation of the harmony between faith and natural science, a view which has since been reaffirmed in the declaration Gravissimum Educationis (1965). In order to attain this, education curricula would need to incorporate elements that would not only enable students to develop intellect and reasoning skills for the acquisition of scientific knowledge, but also for the formation of a mature attitude towards their social and moral responsibilities, and to apply their intellect and skills for these social purposes. Such a balanced approach would enable those who experienced a Catholic education to develop the mature measure of the fullness of Christ and a deeper love of God. In turn, they would be able to reflect their Christian values in all walks of life, through making responsible decisions, exercising the right judgements and in prioritising the common rather than private good, bearing witness to the hope that is in them and playing a crucial part in forming and maintaining the Christian societies around them. Cardinal H.E Martino (2010) states that:

"Catholic schools in a particular way should incorporate, to the extent possible, the social doctrine of the Church into their curricula, and in this way assist ... the formation 
of young people with Catholic consciences, who are able to discern well the teachings of the Church, including when it comes to issues of justice and peace." (212)

Non-profit management and social entrepreneurship courses present a good opportunity to embed Catholic social teaching into commercially orientated curricula. In particular, the relatively recent emergence of social entrepreneurship courses presents the opportunity to align Catholic Social Teaching with a wider audience of business students who have no intention of entering a career in the non-profit sector. The popularity of non-profit management courses in Catholic universities would not be a surprise to most people. In an extensive census of nonprofit management courses conducted by Mirabella and Wish (2001), it was found 39 institutions and departments within 36 private universities offered such courses at the turn of the century. Out of these, 12 of the courses were found in 10 Catholic universities (Table 1). Given that only around 200 out of 1800 private universities in the US are Catholic affiliated, this suggests that Catholic universities punched above their weight in the delivery of these courses. However, as social entrepreneurship courses have only become popular for a relatively short period of time, questions may still be asked of their relevance and effectiveness, and consequently, the take-up of these courses is likely to be even more selective than non-profit management courses. The question of whether Catholic universities embrace social entrepreneurship courses at a relatively early stage depends on two aspects. First, whether Catholic universities believe that social entrepreneurship courses can play a role in fulfilling their social mandate; and second, assuming that the first aspect is accepted, whether Catholic universities are in general quick in adapting to new learning materials for the purpose of enriching their social mission. In relation to the first aspect, a question can be asked as to how receptive the Catholic Church is towards entrepreneurial endeavours. At first glance, the two concepts of entrepreneurship and Catholicism appear incompatible. The teaching of the impossibility of serving both God and Mammon is deeply embedded within the Christian tradition (Vernon, 2011). Entrepreneurship is at the core of neo-liberalism and is often portrayed as an extreme form of capitalism (Fuller, 2013; Minniti and Bygrave, 2005). Nevertheless, it has also been suggested that two key concepts of Catholicism, subsidiarity and the right to private property, underpin the notion of entrepreneurship (Grotenhuis, 2015). One of the earliest references to entrepreneurship was by Pius XII (1956), who, in addressing the Italian National Congress for Small Industry, stated that:

Among the motives that justified the holding of your convention, you have given the first place to a vindication of the indispensable functions of the private entrepreneur. The latter exhibits in an eminent degree the spirit of free enterprise to which we owe the remarkable progress that has been made especially during the past fifty years, and notably in the field of industry. P.50

The usage of entrepreneurship can be accepted within the Catholic Social Teaching framework, it has been argued, as long as it is being applied to promote human dignity, subsidiarity, solidarity, and common good (Grotenhuis, 2015). Social entrepreneurship, in particular, fits into such a framework.

Insert Table 1 here 
In relation to the second point, studies on management innovation suggest that, in devoting resources to adopting innovations early, organisations are in fact taking considerable risks due to high uncertainties regarding the eventual success of the venture (Chesbrough and Crowther, 2006). Are Catholic universities entrepreneurial enough to take on such risk and become early education innovators by investing in the relatively unproven social entrepreneurship courses? Indeed, it is not uncommon amongst Catholic education literature to urge the exercise of caution towards the adoption of innovation too fast and too recklessly (Sibley, 2016). Others suggested that the inherited rigidity and inflexibility of faith-based organisations could hinder their speed and agility in adopting to the changing world (De Kadt, 2009). However, it does not need to be so. In Gravissimum Educationis (1965), the Council recognises that teachings on social justice need to be stimulating, and that students' interest in social justice developed from the learning needs to be maintained beyond their time in education. This requires a motivation-led, rather than an imposed, approach in which a special atmosphere is created where acts of charity and justice should be supported and cherished. In addition, the Gravissimum Educationis (1956) stresses the importance of developing pedagogical skills that are in keeping with contemporary society. This suggests that the course contents should not be rigidly derived, but be flexible and evolve around innovative concepts and successful emerging practices. These points suggest that Catholic universities would not hesitate to develop new and innovative courses, if they believed that such courses could enhance their ability to deliver their social mandate.

The above discussion allows us to derive the following two hypotheses:

H1: Catholic affiliation is found to be positively correlated with the provision of nonprofit management courses to business students.

H2: Catholic affiliation is found to be positively correlated with the provision of social enterprise courses to business students.

The first one serves a confirmatory purpose as there is strong evidence to suggest that nonprofit management courses are well embedded as part of Catholic Social Teaching. The second hypothesis is our main research focus, as we know very little about how social entrepreneurship courses are being perceived by Catholic universities, compared to other universities. If social entrepreneurship can indeed thrive within Catholic universities, more so than in other universities, it signifies not only that they would embrace innovative pedagogies and course contents with speed and flexibility, but that they also would not hesitate to utilise entrepreneurship tools to address business problems.

\section{Methodology}

\section{Sample}

We began with the 2014-2015 database of the Association to Advance Collegiate Schools of Business (AACSB) accredited schools and selected only those that were USA based. We then visit the online undergraduate and postgraduate catalogues of each university to search for social entrepreneurship courses, and go through the course descriptions. We then collate this with information obtained from various sources. After excluding some samples with missing variables, a final sample size of 501 is obtained. In order to reduce missing values, the researchers visit the website of the universities when missing values occur to manually search and input the missing information. 


\section{Measures}

We have two dependent variables in our analysis. In Model 1 we denote 1 to those offering non-profit management courses to business school students, and 0 as otherwise. We include all courses focusing on the leadership and management of non-profit organizations, charities and other voluntary bodies, but disregard courses with non-profit accounting and finance focuses as the latter are often required by the professional bodies to include ethics related modules as a one of the conditions of obtaining professional accreditation to such courses.

In Model 2, we denote 1 to those offering social enterprise courses to business school students, and 0 as otherwise. We include courses emphasizing the start-up, development and management of entrepreneurial social ventures, but exclude short, non-curricula initiatives such as social entrepreneurship boot camps ${ }^{4}$, social business plan competitions ${ }^{5}$, and other nonaccredited short seminars. We also exclude courses from other departments that are typically not made available to business students, but kept university-wide courses that business students can enrol onto.

The independent variable of this study is Catholic orientation, measured by the university's Catholic affiliation (coded as 1 , otherwise 0 ).

Control variables in this study are related to the institutional structure, social emphasis, and entrepreneurial emphasis of universities. Control variables in relation to institutional structure include log of endowment, number of student enrolments, whether or not the university is considered to be an Ivy League University. Log of endowment is a proxy to financial wealth. It would be expected that the variable is positively correlated with the decision as to whether social entrepreneurship and non-profit management courses are offered to business students, as it reflects, in an external context where public funding is in continuous decline (Kelderman, 2011), what Cyert and March (1963) would consider the 'slack' resources that a university can discretionarily place into a course that many would not consider as the core component of their business programmes, but which is nevertheless beneficial to their students (Rutherford et al., 2012).

The number of student enrolments is a proxy to size. Size is likely to play a role in the diversity of courses offered within the curriculum, as a large size reduces the overhead costs for running additional courses.

The 'Ivy League' University label is a proxy to institutional reputation (coded 1 as Ivy League University, otherwise 0). Inclusion in the Ivy League University group has traditionally been seen as the sorter and allocator of elite status (Bourdieu, 1990). As these institutions would be expecting their students to excel in the world of work and, at some point in their life, be propelled into important leadership roles in all segments of society, there is an expectation that a well-rounded educational process, beyond the specialization of subjects, is provided to students in keeping with Newman's or Dewey's ideals (Trow, 2007). For this, developing a socially responsible mindset is widely seen as particularly crucial (Pfeffer, 1977). Therefore we expected the variable to positively correlate with the offerings of social entrepreneurship and non-profit management courses to business students. We adopt a non-canonical definition of Ivy League universities encompassing not only the original Ivies, but also those classified as hidden and public Ivies by Greene and Greene (2000) and Moll (1985) ${ }^{6}$. 
Control variables in relation to social emphasis is a measurement of social and community engagement and sustainability orientation. This is measured by the number of students, graduates and alumni who classify themselves, under the section, 'what they do', to be involved in 'community and social services' on LinkedIn, adjusted for the number of students. We expect that such involvement is positively related to their universities offering courses in social entrepreneurship and non-profit management. As a self-reported variable, this measure reflects the prevalence of social and community engagement by encompassing all kinds of social and community related behaviours. Thus, whilst the measure may not be the most accurate reflection of the actual number of students engaging in such professions, it indicates the receptivity to social and community engagement as a concept amongst peers.

Finally, entrepreneurship engagement reflects how deeply an entrepreneurial culture is embedded into a university. It indicates how well a university has done in offering a supportive environment to enable its students to develop crucial enterprising attributes, such as risk-taking and action propensities, as well as offering technical and other supports during the gestation period, to facilitate the development of business ventures in a timeframe that is most suitable for them (Kwong and Thompson, 2015). The measurement that we have chosen is the number of entrepreneurs amongst staff, students and graduates who successfully obtained venture capital recorded on Crunchbase, after controlling for the size of the student population. The measure is geared towards high growth-orientated entrepreneurs, the development of which requires much more effort, but also more determination, with literature suggesting that support from universities during the gestation stage plays a key role in their formation and also development (Gorman, et al., 1997; Etzkowitz, 2002). We expect this variable to be associated with the offering of social enterprise courses, but not with non-profit management courses.

\section{Data Analysis Process}

Our data analysis will be divided into two parts. In the first part, descriptive statistics will be provided in order to gain an overview of the differences between Catholic universities and other universities in terms of a number of their attributes. Information such as means, standard deviations, and correlations of variables will be used for the analysis.

In the second part, we deploy binary logistic regressions to test our hypotheses given the dichotomous nature of the dependent variables. The control and independent variables will be introduced in two steps. In the first step, control variables will be introduced in Models 1a and 2a. In the second step, the independent variable, Catholic affiliation, is introduced in the full models in Models $1 \mathrm{~b}$ and $2 \mathrm{~b}$.

\section{Results}

\section{Descriptive statistics}

Table 2 provides a breakdown of the social entrepreneurship and non-profit management course provision by the level of delivery. Out of 501 universities within the sample, $66(13.2 \%)$ universities offer non-profit management courses to their business students at any level. Out of these, 30 offer such courses at UG level, 45 at PG level, and a further 9 offer such courses at both UG and PG levels. 136 (27.1\%) universities offer social entrepreneurship courses to their business students at any level. Out of these, 81 offer such courses at UG level, 73 at PG level, and a further 18 offer such courses at both UG and PG levels. 
Insert Table 2 near here

In terms of the religious affiliation of the universities within the sample (Figure 1), the overwhelming majority of the universities $(\mathrm{N}=40,84 \%)$ are not affiliated with any religion. The largest faith university group is Catholic, which has 49 universities and consisted of 10\% of the sample. Protestant is the second largest group, consisting of 30 universities and $6 \%$ of the sample. Two other universities are of other religious affiliation (Jewish, Latter-Day Saints).

\section{Insert Figure 1 near here}

In terms of the breakdown of the non-profit management course provision by religious affiliation (Table 3), it is apparent that faith-based universities are considerably more likely to offer such courses to their business students than those that do not belong to any religion. Only $12.6 \%$ of universities $(\mathrm{N}=47)$ with no religious affiliation offer such courses to their business students, compared to $22.4 \%$ of Catholic universities $(\mathrm{N}=11)$ and $23.3 \%$ of Protestant universities $(\mathrm{N}=7)$.

Insert Table 3 near here

A similar story can also be found in terms of the provision of social entrepreneurship courses (Table 4). Amongst universities with no religious affiliation, 24\% of those ( $\mathrm{N}=102)$ offer these courses to their business students. Such a figure is considerably lower than the $40 \%$ figure for those of both Catholic $(\mathrm{N}=20)$ and Protestant $(\mathrm{N}=12)$ faiths.

Insert Table 4 near here

The descriptive analysis of the comparison between the take-up rate of social entrepreneurship and non-profit management courses amongst universities of different faiths provides an interesting overview as reference, but nevertheless is not the core part of our research. Therefore, for the regression analysis, we shall focus on the comparison solely between Catholic universities and other universities.

\section{Model fit of the regression analysis}

The two models are presented in Tables 4 and 5. Models 1a and 2a introduce the control variables in the first step. In terms of model fit, overall the models appear to be a good fit for the data. The omnibus tests using chi-squared statistics were significant in both models, suggesting that there is a significant relationship between the predictors and the dependent variable. We also conducted the Hosmer and Lemeshow test which was found to be insignificant in all cases and thereby indicates that the models adequately fit the data (Hosmer 
and Lemeshow, 1989). Overall, the percentage of observations correctly predicted in our models is between 72.9 and 86.8 , which is considered to be reasonably good.

When the independent variable, Catholic affiliation, is introduced in Model $1 b$ and $2 b$, all of the above measurements remain good. As interpreting the results of logistic regression is less straightforward than ordinary least-squares regression, we provided here not only the $\mathrm{R}^{2}$, but also two measures of pseudo $\mathrm{R}^{2}$. With the introduction of the control variables in Models $1 \mathrm{~b}$ and $2 \mathrm{~b}$, the pseudo $\mathrm{R}^{2}$ have, compared with Models 1a and 2a, increased in both cases.

Negelkerke $\mathrm{R}^{2}$ has gone up from 0.064 to 0.079 in Model 1, and from 0.302 to 0.0311 in Model 2. Similarly, Cox and Snell $\mathrm{R}^{2}$ have gone up from 0.035 to 0.043 in Model 1, and from 0.208 to 0.214 in Model 2. The $-2 \log$ likelihood functions have also improved in all three models, having gone down from 372.655 in Model 1a to 368.680 in Model 1b, and from 469.046 to 4640953 in Model 2. These figures suggest that the introduction of Catholic affiliation has improved the models, and therefore its inclusion can be justified.

\section{Regression Analysis for Non-profit management course provision}

Table 5 present the results for non-profit management course offerings to business students. In Model 1a the control variables in relation to institutional structure are introduced. Ivy League Universities are found to be positively and significantly $(p=0.01)$ correlated with the dependent variable, with the odds ratio of 3.395 suggesting that these universities, compared to the rest in the sample, are over three times as likely to offer non-profit management courses to business students than non-elite universities. The number of students, alumni, and faculties that are reported to be engaging in the social and community sectors is found to be positively and significantly $(p=0.05)$ correlated to non-profit management course offerings. Size is also found to have an effect, although the relationship between the number of students enrolled and the offering of such courses is only significant at the $10 \%$ level $(p=0.10)$. The results for these control variables are largely as expected and consistent with the existing literature. No significant relation can be found between the offering of non-profit management courses and the other two control variables, log of endowment and entrepreneurship engagement. The lack of relationship with the latter should not come as a surprise, as non-profit management courses do not normally have a strong entrepreneurship focus.

Insert Table 5 near here

Model $1 \mathrm{~b}$ provides the full model where the independent variable, Catholic affiliation, is introduced. In this model both Ivy League Universities and Social and Community Engagement remain positively significant respectively at a $1 \%$ and $5 \%$ level. Catholic affiliation, the independent variable, is found to be positively correlated with the dependent variable at a 5\% level. More specifically, the odds-ratio of 2.264 suggests that religious affiliation increases the likelihood of a university to adopt non-profit management courses by over two times. Thus the finding supports hypothesis 1.

\section{Regression Analysis for Social Enterprise Course Provision}


Table 6 present the results for social enterprise course offerings to business students. Model 2a introduces the control variables in relation to institutional structure. It is found that $\log$ of endowment is positively and significantly $(p=0.01)$ correlated with the decision as to whether courses on social enterprise will be offered to business students. A positive and significant $(p=0.01)$ relationship can also be found with enrolment. The variable 'social and community engagement' is found to be positively and significantly $(p=0.05)$ related to social entrepreneurship course offerings. The variable 'entrepreneurship engagement' is positively correlated with social entrepreneurship course offering, at a 5\% level. Belonging to the Ivy League university group is positively correlated with social entrepreneurship courses offering, but only at a $10 \%$ level. These results for the control variables are as expected and consistent with the existing literature.

Insert Table 6 near here

The independent variable, religious affiliation, is introduced in Model 2b. Almost all control variables remain unchanged, with the exception of Ivy League universities which become significant at a $5 \%$ level. Catholic affiliation is found to be positively and significantly $(p=0.05)$ correlated with the offering of social enterprise courses. The odds-ratio of 2.048 suggests that universities with Catholic affiliation within the sample are over twice as likely to offer social enterprise courses to their business students, compared to universities without such affiliation. Therefore hypothesis 2 is supported.

\section{Discussion and Conclusion}

The findings confirm both of the hypotheses. First, our study confirmed that Catholic universities are significantly more likely than others in the sample to offer non-profit management courses to business students, after controlling for other institutional factors. This is consistent with the finding from the early survey of non-profit management conducted by Mirabella and Wish (2001), as well as other anecdotal evidences, such as their disproportionately strong presence and high-placed finish on non-profit courses' rankings conducted by USA News (2016) and Top University Degrees (2016). The second hypothesis in relation to social entrepreneurship courses, that after controlling for other institutional factors, Catholic universities are significantly more likely to offer these courses, is also confirmed.

With the two hypotheses of the research confirmed, we now return to answer some of the questions we posed earlier in the paper. First, we asked whether Catholic universities believe that social entrepreneurship courses can play a role in fulfilling their social mandate. The answer is a 'yes'. This suggests that Catholic universities view the notion of social entrepreneurship to be compatible with Catholicism, and is deemed a useful instrument in their Catholic social teaching toolbox. This is consistent with the increasingly held view that, if used in a positive way, popular instruments within the free market can be used to address its ills and inadequacies (Grotenhuis, 2015). Second, we asked whether Catholic universities are generally quick in adapting to new learning materials for the purpose of enriching their social mission. Given that these courses have only been around for less than two decades and have only become popular since the mid-to-late 2000s, the disproportionately high offering of these courses by Catholic universities suggest that they are indeed the early adopters. As adopting innovations 
early often requires organisations to devote significant investments in terms of resources and knowledge (Chesbrough and Crowther, 2006), the fact that Catholic universities are adopting them early suggests that they are ready to invest in curriculum development to ensure the innovativeness of their Catholic social teaching agenda. This requires them to develop a good understanding of changes in external context in terms of educational innovation, as well as having the flexibility to divert resources into these courses without facing considerable hindrances. Finally, with the success of these courses being far from certain, their take-up requires Catholic universities to be entrepreneurial and willing to take risks.

There are a number of research limitations to the paper. Social enterprise courses are often characterized as a mixed bag involving various objectives, with some trying to support those who intend to start a social business and others to encourage social and civic awareness, or simply to increase student satisfaction through providing a different experience (Brock, 2008; Kwong, Thompson and Cheung, 2012). The different motives in offering social enterprise courses is something that we are unable to capture within our data and therefore more research along this line would further enhance our understanding of the supply-side of social enterprise course provision. In relation to this, our study was unable to capture the different pedagogical approaches adopted by different universities as we were only able to examine the course descriptions but not the content. Whilst a considerable amount of literature is beginning to emerge in relation to this, a systematic review of all courses available is still lacking. We also cannot capture the length and the depth of these courses. In addition, as we focus only on formal social enterprise courses that are available to business students, we are unable to capture universities adopting an extracurricular approach towards social entrepreneurship, such as organizing a social enterprise boot camp, social business plan competition, or offering service learning opportunities in social enterprises. More comprehensive studies including the above could enhance our understanding of the supply of social enterprise courses within universities. Further study could also examine the differences between undergraduate and postgraduate levels of provision to see whether different pedagogies may have emerged as a result of the different student groups. 


\section{Notes}

${ }^{1}$ The term 'bricolage' was first coined by Levi-Strauss $(1967,17)$ as "making do with whatever is at hand". This involves use of resources-at-hand, such as physical artefacts, skills or ideas, that are accumulated on the principle that 'they may always come in handy', rather than acquired in response to demands of a specific application for which they have proven capabilities (Baker and Nelson, 2005; Desa and Basu, 2013; Lanzara, 1999). Bricolage implies a bias towards action involving the deployment and integration of resources in novel ways rather than conforming to norms and standard practices originally intended for these resources (Jones, MacPherson, and Jayawarna 2014, 155, Baker and Nelson 2005).

${ }^{2}$ Social entrepreneurship courses often intend to encourage students to engage in social entrepreneurial activities in their lives. In Kwong, Thompson and Cheung (2012), for instance, one of the assignments from a social entrepreneurship course that was examined asked the students to write a business plan about a social business idea that they could pursue. Students came up with many different ideas, some related to their personal needs (e.g. student storage cooperative, student consultancy, elderly café), hobbies (e.g. local cycling initiative, cookies factory), but, in quite a few cases, also their career interests (e.g. investment network, medical supplies, rehab of ex-prisoners). In one case, the student proposed a social business to be operated within a for-profit business that he was hoping to start up, as part of its corporate social responsibility initiative.

${ }^{3}$ An example of the expansion is the Columbia Business School, where the Tamer Center for Social Enterprise developed a range of social entrepreneurship courses within the curriculum. These include "Social Entrepreneurship: A global perspective" as the introductory courses offering students an overview of the development of social entrepreneurship worldwide, to the more practical courses including "Launching Social Ventures" which provides students the managerial tools specifically for social ventures, and "Social Venture Incubator", where students 'have a go' in turning the different social venture ideas into reality. Another good example of the offering of social entrepreneurship teaching can be found at the Fuqua Business School of the Duke University, where the participation on the social entrepreneurship course, together with a number of social and entrepreneurship orientated courses, enabled students to attain a social entrepreneurship concentration within their undergraduate and MBA programs.

${ }^{4}$ Boot camps refers to off-campus residential entrepreneurship courses, which typically lasts between a few days to 2 weeks. Many universities, such as Stanford University and the University of Colorado, Boulder, have organised boot camp for aspiring social entrepreneurs. For further discussion on boot camps please refer to Kwong et al. (2012).

${ }^{5}$ Social business plan competition refers to business which involves teams of students working on a business plan for a specific social venture. Typically, the teams will be offering managerial workshops as well as mentor supports. The competition is often organised in the form of a pitching event where students would be given time to present their business idea in front of a panel of judges consisting of academics, social entrepreneurs and venture capitalists. Many business schools, including the Haas Business School (UC-Berkeley), and 
Seattle Pacific University, have been running such competition for many years. Sometimes these competitions are fed into inter-university competitions such as the Global Social Venture Competition (www.gsv.org), or the Hult Prize which offered a total of US $\$ 1,000,000$ seed fund each year to promising social ventures (http://www.hultprize.org/). For further discussion on social business plan please refer to Kwong, Thompson and Cheung (2012).

\section{Notes on Contributors}

Cherry Cheung is a senior lecturer and the group lead of the Business Ethics \& Corporate Social Responsibility Research Group at the Business School of London South Bank University. Her research interests include management and religion and entrepreneurship, enterprise education, business law and entrepreneurship amongst those with Autism Spectrum Disorder/ Condition.

Sujun Fieldhouse is an Economic Development Officer at the Southend-on-Sea Borough Council. She was formerly a research manager at the Essex Business School, University of Essex. Her research interest is on the impact of enterprise ecosystem on the entrepreneurial and socially-entrepreneurial behaviours of individuals.

Caleb Kwong is a senior lecturer and the undegraduate director of Essex Business School, University of Essex. His current research interests include enterprise education, religion and entrepreneurship, social entrepreneurship, entrepreneurship at the time of war and conflict, refugee entrepreneurship, and entrepreneurship amongst those with Autism Spectrum Disorder/ Condition.

\section{References}

Aspen Institute (2001). Where will they lead? MBA student attitudes about business and society. New York: Aspen Institute for Social Innovation Through Business.

Austin, J., Stevenson, H. and Wei - Skillern, J., (2006). Social and commercial entrepreneurship: same, different, or both?. Entrepreneurship Theory and Practice, 30(1), pp.1-22.

Benedict XVI. (2009) Caritas in Veritate. Encyclical letter. London: Catholic Truth Society

Brammer, S., Jackson, G. and Matten, D., 2012. Corporate social responsibility and institutional theory: New perspectives on private governance. Socio-Economic Review, 10(1), pp.3-28.

Brock, D. D., \& Steiner, S. (2009). Social entrepreneurship education: Is it achieving the desired aims?. USASBE 2008 Proceedings, Available at SSRN 1344419.

Bourdieu, P., (1990), In Other Words: Essays Towards a Reflexive Sociology, Cambridge: Polity

Chesbrough, H. and Crowther, A.K., (2006). Beyond high tech: early adopters of open innovation in other industries. $R \& D$ Management, 36(3), pp.229-236.

Cyert, R.M. and March, J.G., (1963). A behavioral theory of the firm. Englewood Cliffs, NJ, 2.

De Kadt, E., (2009). Should God play a role in development?. Journal of International Development, 21(6), pp.781-786. 
Etzkowitz, H., (2002). Incubation of incubators: innovation as a triple helix of universityindustry-government networks. Science and Public Policy, 29(2), pp.115-128.

Fuller, S., (2013). 'Never let a good crisis go to waste': moral entrepreneurship, or the fine art of recycling evil into good. Business Ethics: A European Review, 22(1), pp.118-129.

Ghoshal, S. (2005). Bad management theories are destroying good management practices. Academy of Management learning \& education, 4(1), 75-91.

Gorman, G., Hanlon, D. and King, W., (1997). Some research perspectives on entrepreneurship education, enterprise education and education for small business management: a ten-year literature review. International small business journal, 15(3), pp.56-77.

Grace, G., 2013. Catholic social teaching should permeate the Catholic secondary school curriculum: an agenda for reform. International Studies in Catholic Education, 5(1), pp.99109.

Greene, H. and Greene, M. (2000). Hidden Ivies: Thirty Colleges of Excellence. New York: HarperCollins. ISBN 0-06-095362-4.

Grotenhuis, R (2015) Cordaid, Social Entrepreneurship and Catholic Social Thought. Cordaid: the Hague.

Hadas, E., (2009). The Credit Crunch: Making Moral Sense of the Financial Crisis. Catholic Truth Society: London

Howorth, C., Smith, S. M., \& Parkinson, C. (2012). Social learning and social entrepreneurship education. Academy of Management Learning \& Education,11(3), 371-389.

John Paul II (1992) Catechism of the Catholic Church. Vatican City, Rome.

John Paul II, (1998) Lenten message. Vatican City, Rome.

Kelderman, E., (2011). As state funds dry up, many community colleges rely more on tuition than on taxes to get by. The Chronicle of Higher Education, 57, p.23.

Kwong, C. C., Thompson, P., \& Cheung, C. W. (2012). The effectiveness of social business plan competitions in developing social and civic awareness and participation. Academy of Management Learning \& Education, 11(3), 324-348.

Kwong, C. Thompson, P. Cheung, C. and Manzoor, H. (2012) The Role of Environment in Fostering Conductive Entrepreneurial Learning - Teaching the 'Art' of Entrepreneurship in Summer Boot Camps', Journal of General Management, 38, 1, 45-71.

Kwong, C. and Thompson, P. (2016) The When and Why: Student Entrepreneurial Aspirations, Journal of Small Business Management, 54:1. 299-318 (ABS3, Impact factor 2015 1.937, ERA A)

Lawrence, T., Phillips, N., \& Tracey, P. (2012). From the guest editors: Educating social entrepreneurs and social innovators. Academy of Management Learning \& Education, 11(3), 319-323.

Leo XIII (1891) Rerum Navarum. Encyclical letter. Vatican City, Rome 
Longley, C., (2014). Just money: How catholic social teaching can redeem capitalism. Working Paper. Theos Think Tank: London

Martino, Renato Raffaele C.H., (2010). What Catholic schools can do to advance the cause of justice and peace in the world. International Studies in Catholic Education, 2(2), pp.212-216.

Mirabella, R.M. and Wish, N.B., (2001). University-based educational programs in the management of nonprofit organizations: An updated census of US programs. Public Performance \& Management Review, 25(1), pp.30-41.

McCabe, D. L., \& Trevino, L. K. (1995). Cheating among business students: A challenge for business leaders and educators. Journal of Management Education, 19: 205-218.

Minniti, M. and Bygrave, W., (1999). The microfoundations of entrepreneurship. Entrepreneurship: Theory and Practice, 23(4), pp.41-41.

Moll, R., (1985). The public ivys: a guide to America's best public undergraduate colleges and universities. Viking Adult: NYC

O'Neill, M., (2005). Developmental contexts of nonprofit management education. Nonprofit Management and Leadership, 16(1), pp.5-17.

Paul VI. (1967). Populorum Progressio (1967) encyclical letter. Vatican City, Rome

Pius XI. (1931). Quadragesimo anno. Encyclical letter. Vatican City, Rome

Paul VI. (1967). Gravissimum Educationis. Encyclical letter. Vatican City, Rome

Pfeffer, J. (1977). The ambiguity of leadership. Academy of Management Review, 2(1), 104112.

Pius XI. (1956) The Small Business Manager. An address of Pope Pius XII to the First National Congress of Small Industry, taken from Pope Speaks, Spring/Summer, 1956.

Rasche, A., Gilbert, D. U., \& Schedel, I. (2013). Cross-disciplinary ethics education in MBA programs: rhetoric or reality?. Academy of Management Learning \& Education, 12(1), 71-85.

Rutherford, M. A., Parks, L., Cavazos, D. E., \& White, C. D. (2012). Business ethics as a required course: Investigating the factors impacting the decision to require ethics in the undergraduate business core curriculum. Academy of Management Learning \& Education, 11(2), 174-186.

Sibley, A., (2016). Can there be a Catholic economics? An essay to assist the work of teachers in Catholic schools internationally. International Studies in Catholic Education, 8(2), pp.202215.

Spitzeck, H. and Hansen, E.G., (2010). Stakeholder governance: How stakeholders influence corporate decision making. Corporate Governance: The international journal of business in society, 10(4), pp.378-391.

The Second Vatican Council (1965) Gaudium et Spes. Vatican City, Rome. 
Top Management Degrees (2016). Top 50 Nonprofit Management Master's Degree Program 2016. Accessed from: http://www.topmanagementdegrees.com/rankings/best-nonprofitmanagement-degree-programs-2016/. Accessed on 21 Dec 2016

Trow, M. (2007). Reflections on the transition from elite to mass to universal access: Forms and phases of higher education in modern societies since WWII. In International handbook of higher education (pp. 243-280). Springer Netherlands.

U.S. Bishops' Committee (1986) Economic Justice for All. Pastoral Message of the United States Conference of Catholic Bishops, 1986.

USA News, (2016). Best Grad Schools: Nonprofit Management. Accessed from: http://gradschools.usnews.rankingsandreviews.com/best-graduate-schools/top-public-affairsschools/nonprofit-management-rankings. Accessed on 21 Dec 2016.

Vernon, M. (2011) Is Christianity compatible with wealth? The Guardian, Wednesday 28 December 2011.

Young D. (1999) Non-profit management studies in the United States: Current Development and future prospects, Journal of Public Affairs Education, 5, 1. 13-23

Figure 1. Breakdown of the religious affiliations of the universities within the sample 


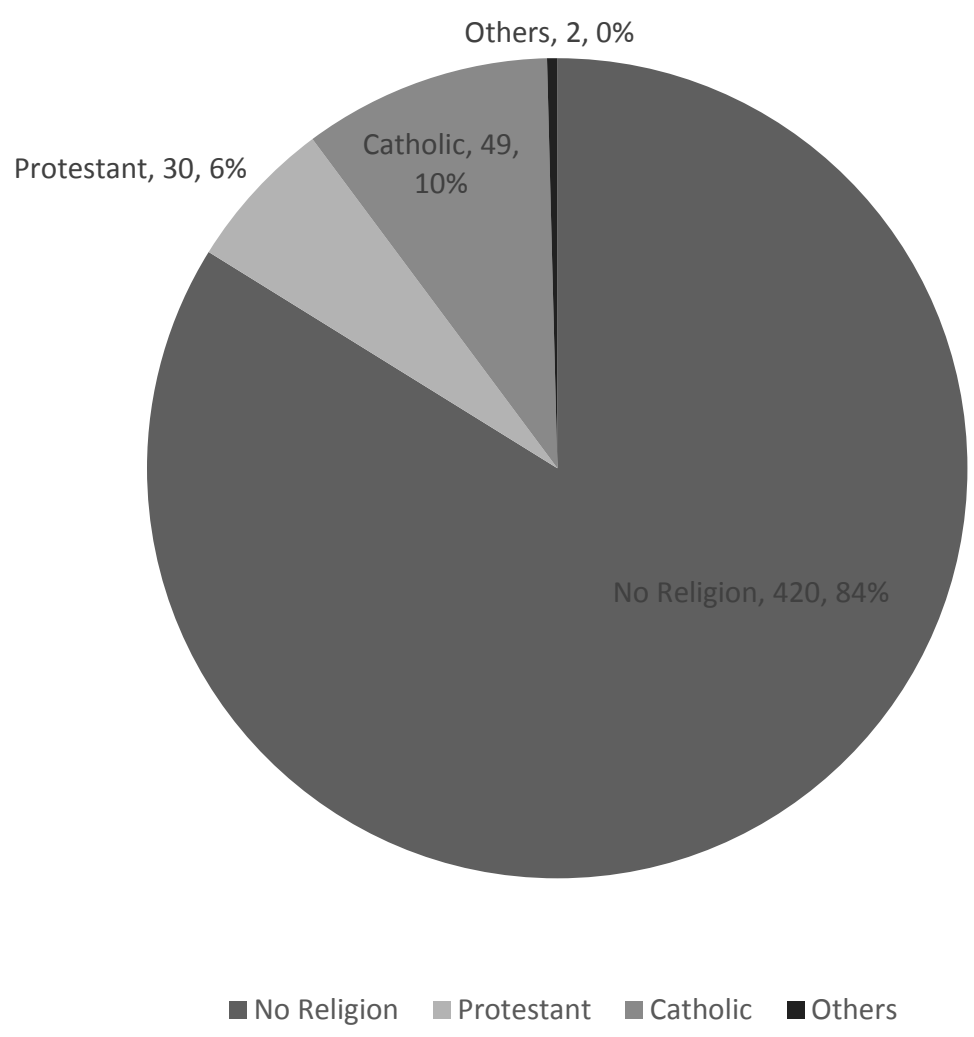

Table 1. Catholic universities with a non-profit management courses as reported in Mirabella and Wish (2001)

\begin{tabular}{|l|l|l|}
\hline Name & Location & $\begin{array}{l}\text { Programs that offered non-profit } \\
\text { entrepreneurship course components }\end{array}$ \\
\hline De Paul University & Chicago, Illinois & MS Public Service Management \\
\hline Loyola University & Chicago, Illinois & Not provided \\
\hline Marywood University & Scranton, Pennsylvania & MPA \\
\hline Regis University & Denver, Colorado & Master of non-profit management \\
\hline Saint Mary's University & Winona, Minnesota & MA in Philanthropy and development \\
\hline Seattle University & Seattle, Washington & Master in not-for-profit leadership \\
\hline Seton Hall University & South Orange, New Jersey & MPA \\
\hline Saint Louis University & St. Louis, Missouri, & $\begin{array}{l}\text { MSW, MSW in School of Social } \\
\text { Services, MPA in Park College (x3) }\end{array}$ \\
\hline University of San Francisco & San Francisco, California & Master of non-profit administration \\
\hline University of St. Thomas & Miami Gardens, Florida & MBA \\
\hline
\end{tabular}

Table 2. Breakdown of Social Entrepreneurship and Non-profit Management Course offered to Business Students at UG and PG levels

\begin{tabular}{|l|l|l|l|l|}
\hline & $\begin{array}{l}\text { Offered at UG } \\
\text { level }\end{array}$ & $\begin{array}{l}\text { Offered at PG } \\
\text { level }\end{array}$ & $\begin{array}{l}\text { Offered at } \\
\text { either UG, or PG } \\
\text { levels, or both }\end{array}$ & $\begin{array}{l}\text { Offered at both } \\
\text { UG and PG } \\
\text { levels }\end{array}$ \\
\hline $\begin{array}{l}\text { Non-profit } \\
\text { Management Courses }\end{array}$ & 30 & 45 & 66 & 9 \\
\hline
\end{tabular}




\begin{tabular}{|l|l|l|l|l|}
\hline & & & & \\
\hline Social & 81 & 73 & 136 & 18 \\
Entrepreneurship & & & & \\
Courses & & & & \\
\hline
\end{tabular}

Table 3. Breakdown of Non-profit Management Course offered to Business Students by Religious Affiliation

\begin{tabular}{|l|l|l|l|l|l|}
\hline & $\begin{array}{l}\text { No Religious } \\
\text { Affiliation }\end{array}$ & $\begin{array}{l}\text { Catholic } \\
\text { Affiliation }\end{array}$ & $\begin{array}{l}\text { Protestant } \\
\text { Affiliation }\end{array}$ & $\begin{array}{l}\text { Other } \\
\text { Affiliation }\end{array}$ & Total \\
\hline $\begin{array}{l}\text { Non-profit } \\
\text { Management } \\
\text { Courses }\end{array}$ & $47(12.6 \%)$ & $11(22.4 \%)$ & $7(23.3 \%)$ & $1(50 \%)$ & $66(13.2 \%)$ \\
\hline $\begin{array}{l}\text { No Non-profit } \\
\text { Management } \\
\text { Courses }\end{array}$ & $373(87.4 \%)$ & $38(77.6 \%)$ & $23(76.7 \%)$ & $1(50 \%)$ & $435(86.8 \%)$ \\
\hline Total & $420(100 \%)$ & $49(100 \%)$ & $30(100 \%)$ & $2(100 \%)$ & $501(100 \%)$ \\
\hline
\end{tabular}

Table 4. Breakdown of Social Enterprise Course offered to Business Students by Religious Affiliation

\begin{tabular}{|l|l|l|l|l|l|}
\hline & $\begin{array}{l}\text { No Religious } \\
\text { Affiliation }\end{array}$ & $\begin{array}{l}\text { Catholic } \\
\text { Affiliation }\end{array}$ & $\begin{array}{l}\text { Protestant } \\
\text { Affiliation }\end{array}$ & $\begin{array}{l}\text { Other } \\
\text { Affiliation }\end{array}$ & Total \\
\hline $\begin{array}{l}\text { Social Enterprise } \\
\text { Courses }\end{array}$ & $102(24 \%)$ & $20(40 \%)$ & $12(40 \%)$ & $2(100 \%)$ & $\begin{array}{l}136 \\
(27.1 \%)\end{array}$ \\
\hline $\begin{array}{l}\text { No Social } \\
\text { Entrepreneurship } \\
\text { Courses }\end{array}$ & $318(76 \%)$ & $29(60 \%)$ & $18(60 \%)$ & $0(0 \%)$ & $\begin{array}{l}365 \\
(72.9 \%)\end{array}$ \\
\hline Total & $420(100 \%)$ & $49(100 \%)$ & $30(100 \%)$ & $2(100 \%)$ & $501(100 \%)$ \\
\hline
\end{tabular}

Table 5. Logistic Regression Results for Predictors of Non-profit Management Course offered to Business Students (Model 1)

\begin{tabular}{|l|l|l|l|l|}
\hline & \multicolumn{2}{|l|}{ Model 1a } & \multicolumn{2}{l|}{$\begin{array}{l}\text { Model 1b } \\
\text { (full model) }\end{array}$} \\
\hline & B (S.E.) & $\begin{array}{l}\text { Exp } \\
\text { (B) }\end{array}$ & B (S.E.) & $\begin{array}{l}\text { Exp } \\
\text { (B) }\end{array}$ \\
\hline Log Endowment & -0.105 & 0.900 & -0.159 & 0.853 \\
& $(0.174)$ & & $(0.171)$ & \\
\hline Ivy Universities & $\begin{array}{l}1.222^{*} \\
(0.394)\end{array}$ & 3.395 & $\begin{array}{l}1.323^{*} \\
(0.398)\end{array}$ & 3.755 \\
\hline
\end{tabular}




\begin{tabular}{|c|c|c|c|c|}
\hline Enrolment & $\begin{array}{l}0.290^{+} \\
(0.182)\end{array}$ & 1.337 & $\begin{array}{l}0.316^{+} \\
(0.184)\end{array}$ & 1.372 \\
\hline $\begin{array}{l}\text { Social and Community } \\
\text { Engagement }\end{array}$ & $\begin{array}{l}0.027 * * \\
(0.011)\end{array}$ & 1.027 & $\begin{array}{l}0.025 * * \\
(0.011)\end{array}$ & 1.025 \\
\hline $\begin{array}{l}\text { Entrepreneurship } \\
\text { Engagement }\end{array}$ & $\begin{array}{l}-0.036 \\
(0.079)\end{array}$ & 0.965 & $\begin{array}{l}-0.022 \\
(0.079)\end{array}$ & 0.978 \\
\hline Catholic Affiliation & & & $\begin{array}{l}0.817 * * \\
(0.391)\end{array}$ & 2.264 \\
\hline Constant & $\begin{array}{l}-1.926 \\
(1.334)\end{array}$ & 0.146 & $\begin{array}{l}-1.611 \\
(1.293)\end{array}$ & 0.200 \\
\hline $\mathbf{N}$ & 501 & & 501 & \\
\hline $\mathrm{X}^{2}$ & 17.799* & & $21.774^{*}$ & \\
\hline Df & 5 & & 6 & \\
\hline$\%$ correctly predicted & 86.8 & & 86.8 & \\
\hline-2 Log likelihood & 372.655 & & 368.680 & \\
\hline Cox and Snell $\mathbf{R}^{2}$ & 0.035 & & 0.043 & \\
\hline Nagelkerke $\mathbf{R}^{\mathbf{2}}$ & 0.064 & & 0.079 & \\
\hline
\end{tabular}

${ }^{*}$ Sig $p<0.01,{ }^{*}$ Sig $p<0.05$, Sig $p<0.10$

Table 6. Logistic Regression Results for Predictors of Social Entrepreneurship Course offered to Business Students (Model 2)

\begin{tabular}{|c|c|c|c|c|}
\hline & \multicolumn{2}{|c|}{ Model 1a } & \multicolumn{2}{|c|}{$\begin{array}{l}\text { Model 1b } \\
\text { (full model) }\end{array}$} \\
\hline & B (S.E.) & $\begin{array}{l}\text { Exp } \\
\text { (B) }\end{array}$ & B (S.E.) & $\begin{array}{l}\text { Exp } \\
\text { (B) }\end{array}$ \\
\hline Log Endowment & $\begin{array}{l}0.838^{*} \\
(0.208)\end{array}$ & 2.311 & $\begin{array}{l}0.793^{*} \\
(0.212)\end{array}$ & 2.209 \\
\hline Ivy Universities & $\begin{array}{l}0.715^{+} \\
(0.381)\end{array}$ & 2.045 & $\begin{array}{l}0.812 * * \\
(0.385)\end{array}$ & 2.252 \\
\hline Enrolment & $\begin{array}{l}0.470^{*} \\
(0.151)\end{array}$ & 1.602 & $\begin{array}{l}0.497^{*} \\
(0.153)\end{array}$ & 1.644 \\
\hline $\begin{array}{l}\text { Social and Community } \\
\text { Engagement }\end{array}$ & $\begin{array}{l}0.026 * * \\
(0.011)\end{array}$ & 1.026 & $\begin{array}{l}0.023^{* *} \\
(0.011)\end{array}$ & 1.023 \\
\hline $\begin{array}{l}\text { Entrepreneurship } \\
\text { Engagement }\end{array}$ & $\begin{array}{l}0.269 * * \\
(0.121)\end{array}$ & 1.308 & $\begin{array}{l}0.273^{* *} \\
(0.119)\end{array}$ & 1.314 \\
\hline Catholic Affiliation & & & $\begin{array}{l}0.717^{* *} \\
(0.349)\end{array}$ & 2.048 \\
\hline Constant & $\begin{array}{l}-9.096 \\
(1.680)\end{array}$ & 0.001 & $\begin{array}{l}-8.807 \\
(1.700)\end{array}$ & 0.001 \\
\hline $\mathbf{N}$ & 501 & & 501 & \\
\hline$x^{2}$ & 116.826 & & 120.919 & \\
\hline
\end{tabular}




\begin{tabular}{|l|l|l|l|l|}
\hline Df & 5 & & 6 & \\
\hline \%correctly predicted & 72.9 & & 72.9 & \\
\hline -2 Log likelihood & 469.046 & & 464.953 & \\
\hline Cox and Snell $\mathbf{R}^{\mathbf{2}}$ & 0.208 & & 0.214 & \\
\hline Nagelkerke $\mathbf{R}^{\mathbf{2}}$ & 0.302 & & 0.311 & \\
\hline
\end{tabular}

${ }^{*}$ Sig $\mathrm{p}<0.01,{ }^{* *}$ Sig $\mathrm{p}<0.05,{ }^{+}$Sig $\mathrm{p}<0.10$ 